\title{
PENGGUNAAN MODEL SINEKTIK UNTUK MENINGKATKAN KEMAMPUAN MAHASISWA DALAM MENULIS PUISI
}

\author{
Sun Suntini ${ }^{1}$, Figiati Indra Dewi ${ }^{2}$ \\ Program Studi Pendidikan Bahasa dan Sastra Indonesia \\ Fakultas Keguruan dan Ilmu Pendidikan Universitas Kuningan \\ sun.suntini@uniku.ac.id
}

\begin{abstract}
ABSTRAK: Penelitian ini merupakan penelitian tindakan kelas, fokus dari penelitian ini adalah penggunaan model pembelajaran sinektik untuk meningkatkan kemampuan menulis mahasiswa PBSI tingkat II tahun ajaran 2018/2019. Tujuan dari penelitian ini untuk meningkatkan kemampuan mahasiswa dalam menulis puisi dengan memperhatikan pilihan kata yang tepat, pencitraan, pemadatan bahasa, kata konkret, tema, dan amanat. Metode yang digunakan dalam penelitian ini adalah metode Penelitian Tindakan Kelas. Objek penelitian mahasiswa PBSI tingkat II tahun ajaran 2018/2019 dengan jumlah 58 orang. Hasil peneltian 1). Menyusun RPS dengan langkah-langkah sebagai berikut 1) menggunakan teknik tanya jawab anatara mahasiswa dan peneliti/dosen mengenai tema yang sudah ditentukan oleh dosen yaitu "wanita karier"(2) menggunakan teknik analogi langsung mahasiswa menganalogikan wanita karier dengan benda, hewan, kata sifat ada kata positif dan ada kata negatif. Mahasiswa harus mengumpulkan kata-kata tersebut sebanyak-banyaknya untuk dirangkai menjadi sebuah puisi (3) masing-masing mahasiswa disuruh menulis puisi dengan tema wanita karier. (4) menggunakan kriteria penilaian untuk mengukur kemampuan siswa dalam menulis puisi. Tindakan-tindakan tersebut termuat dalam Rancangan Pembelajaran Semester (RPS).2). Proses pelaksanaan pembelajaran menulis puisi, pada awalanya dosen/peneliti melakukan tanya jawab dengan mahasiswa tentang puisi kemudian dosen memberikan tema (wanita karier), para mahasiswa disuruh menulis sebanyak-banyaknya kata-kata yang menganalogikan wanita karier misalnya analogi dengan kata sifat. Analogi dengan binatang. Analogi dengan benda. Kata -kata yang dikumpulkan ada yang negatif ada yang maknanya positif. Selanjutnya setiap mahasiswa harus menulis puisi dengan kata-kata yang sudah ditulis sebelumnya.3). Hasil pembelajaran yang dicapai dapat dilihat pada pencapaian sebagai berikut. Pada siklus I, mahasiswa yang memperoleh nilai di atas 80 hanya ada lima orang dengan nilai rata-rata seluruh mahasiswa 73. Sedangkan pada siklus II siswa yang memperoleh nilai di atas 80 sebanyak 42 orang dengan nilai ratarata seluruh siswa 83. Ini membuktikan bahwa model sinektik yang digunakan oleh peneliti efektif untuk meningkatkan pembelajaran menulis puisi pada mahasiswa PBSI tingkat II tahun ajaran 2018/2019 Universitas Kuningan.
\end{abstract}

KATA KUNCI: model sinektik; kemampuan menulis puisi; mahasiswa PBSI tingkat II tahun ajaran 2018/2019.

THE USE OF THE SYNECTIC MODEL TO IMPROVE COLLEGE STUDENTS 'ABILITY IN WRITING POETRY

\begin{abstract}
This research is a classroom action research, the focus of this research is the use of synectic learning models to improve the writing ability of PBSI level II students in the 2018/2019 school year. The purpose of this study is to improve students' ability to write poetry by considering the right choice of words, imaging, compaction language, concrete words, themes, and mandates. The method used in this study is the Classroom Action Research method. The object of research of PBSI level II students in the 2018/2019 school year was 58 people. Research Results 1). Prepare the RPS with the following steps 1) use question and answer techniques between students and researchers/lecturers on themes that have been determined by the lecturer namely "career women" (2) using direct analogy techniques students analogize hunting women with objects, animals, adjectives there positive words and negative words. Students must collect these words as much as possible to be arranged into poetry. (3) each student is told to write poetry with the theme of career women. (4) using criteria to measure students' ability to write poetry. These actions are contained in the Semester Learning Plan (RPS). 2). The process of learning to write poetry, in the beginning, lecturers/researchers conduct questions and answers with students about poetry then lecturers provide themes (career women), students are told to write as many words as analogous to women who conduct analogy research with adjectives. The analogy with animals. The analogy with objects. Words that are collected are negative and positive. Furthermore, each student must
\end{abstract}


write a poem with words that have been written previously.3). Learning outcomes obtained can be seen when following. In the first cycle, students who scored above 80 there were only five people with an average value of all students 73 . While in cycle II students who scored above 80 were 42 people with an average value for each student 83 . This proves the synectic model used by researchers to improve poetry writing learning in PBSI level II students in 2018/2019 University of Kuningan.

KEYWORDS: synectic model; the ability to write poetry; PBSI level II students in the 2018/2019 school year.

\begin{tabular}{lccc}
\hline Diterima: & Direvisi: & Disetujui: & Dipublikasi: \\
17-01-2020 & 24-03-2020 & $06-03-2020$ & $31-03-2020$ \\
Pustaka & : Suntini, S., \& Dewi, F. I. (2020). PENGGUNAAN MODEL SINEKTIK UNTUK \\
& MENINGKATKAN KEMAMPUAN MAHASISWA DALAM MENULIS PUISI. Fon: Jurnal \\
& Pendidikan Bahasa dan Sastra Indonesia, 16(1), 39-46. \\
DOI & $:$ https://doi.org/10.25134/fjpbsi.v16i1.2506 \\
\hline
\end{tabular}

\section{PENDAHULUAN}

Menulis merupakan salah satu keterampilan berbahasa yang harus dimiliki oleh siswa, dari keempat keterampilan berbahasa (menyimak, berbicara, membaca dan menulis), menulis termasuk keterampilan berbahasa yang dianggap paling sulit. Menurut Tarigan (2008, Hlm. 22) menulis adalah menurunkan atau melukiskan lambanglambang grafik yang menggambarkan suatu bahasa yang dipahami oleh seseorang sehingga orang lain dapat mem`baca lambang dan grafik tersebut. kemampuan menulis siswa harus

diperhatikan dan diberi motivasi agar siswa terdorong untuk terampil dalam mengembangkan keterampilannya dalam menulis (Lisniti, 2017). Jika kita membaca tentang teori-teori cara menulis memang sepertinya mudah tetapi mulai menulis munculah berbagai kesulitan diantaranya sulit mengembangkan ide, gagasan atau cara menyampaikan pesan. Hal ini dirasakan oleh semua orang termasuk mahasiswa yang sedang belajar menulis. Pembelajaran menulis itu proses, butuh waktu yang lama untuk menjadi penulis yang mahir, diperlukan latihan dalam jangka waktu yang panjang (Suntini, 2016). Kegiatan pembelajaran yang terlalu sederhana mempengaruhi sikap dan cara pandang siswa terhadap puisi, khususnya pembelajaran menulis puisi (Supriyadi, 2016).

Dalam mata kuliah Anatomi Puisi mahasiswa diwajibkan menulis puisi minimal dua puluh judul puisi selama satu semester, yang jadi permasalahan berdasarkan hasil wawancara dengan para mahasiswa mereka kesulitan dalam mencipta atau menulis puisi, dari mulai mencari ide sampai teknik menulisnya para masiswa rata-rata masih bingung. Tentu saja hal ini menjadi permasalahan yang harus dicari solusinya, karena tujuan akhir dari pembelajaran menulis puisi di sekolah adalah menumbuhkan rasa cinta dan senang siswa terhadap karya sastra sehingga mereka dapat mempergunakannya secara terampil dalam kehidupan bermasyarakat (Supriyadi, 2016). oleh karena itu peneliti sebagai dosen pengampu mata kuliah Anatomi Puisi akan menggunakan model pembelajaran yang dapat meningkatakan kemampuan atau keterampilan menulis puisi para mahasiswa. Salah satu model pembelajaran yang sudah beberapa kali dicoba di sekolah atau perguruan tinggi lain untuk meningkatkan keterampilan menulis yaitu dengan menggunakan model sinektik. Model pembelajaran yang mengasah kreativitas siswa/mahasiswa dengan cara analogi.

Model sinektik pertama kali digagas oleh William Gordon pada tahun 1961. 
Model ini dikembangkan dari beberapa asumsi tentang psikologi kreativitas, asumsi pertama dengan membawa proses kreatif menuju kesadaran kita dapat secara langsung meningkatkan kreatifitas kreatif secara individu maupun kelompok. Asumsi kedua komponen emosional lebih penting daripada intelektual. Asumsi ketiga unsur-unsur emosional, irasional harus dipahami dalam rangka meningkatkankemungkinan sukses dalam situasi pemecahan masalah.

Pertama kreatifitas penting dalam kehidupan sehari-hari, kedua proses kreatif tidak selamanya misterius, ketiga penemuan atau inovasi yang dianggap kreatif sama rata disemua bidang seni, sains, teknik dan ditandai oleh proses intelektual yang sama. Keempat bahwa penemuan (pola pikir kreatif) individu maupun kelompok tidak berbeda.

Berdasarkan uraian di atas dapat disimpulkan bahwa analisis terhadap proses irasional dan emosional tertentu dapat membantu individu untuk meningkatkan kreatifitas. Aspek irasional dapat dipahami dan dikontrol secara sadar, pencapaian ini dapat melalui penggunaan metafora dan analogi secara seksama merupakan objek sinektik. Dengan kata lain model sinektik dapat dikatakan model pembelajaran dengan cara meningkatkan kreatifitas siswa melalui metafora dan analogi.

\section{METODE}

\section{Metode Penelitian}

Metode yang digunakan dalam penelitian ini yaitu metode penelitian tindakan kelas (PTK), menurut Abdul Rozak (2012, Hlm. 101) Penelitian Tindakan Kelas bersifat situasional, masalah berangkat dari praktik pembelajaran sehari-hari yang benarbenar dirasakan oleh mahasiswa dan dosennya.

\section{Objek Penelitian}

Objek dalam penelitian ini adalah mahasiswa prodi PBSI tingkat satu terdiri dari dua kelas A dan B sebanyak 56 orang Tahun Ajaran 2018/2019.

\section{Teknik Pengumpulan Data}

1) Obsevasi dilakukan pengamatan terhadap siswa dalam proses pembelajaran di dalam kelas. Dalam hal ini yang bertindak sebagai peneliti. mengamati jalannya kegiatan pembelajaran serta mengamati prilaku para mahsiswa pada saat pembelajaran berlangsung.

2) Tes tulis, dalam teknik ini mahasiswa disuruh menulis puisi setelah proses pembelajaran, teknik ini digunakan untuk mengetahui kemampuan mahasiswa dalam hal menulis puisi.

\section{Teknik Analisis Data}

Data dianalisis berdasarkan instrumen yang telah dibuat oleh peneliti yang kemudian diolah secara kuantitatif.

\section{HASIL DAN PEMBAHASAN \\ Proses Pembelajaran siklus I}

1. Kegiatan Awal

Pembelajaran dimulai pada jam kedua pukul 10.00-11.40, seperti pembelajaran pada umumnya dosen mengucapkan salam, mengecek kehadiran mahasiswa, dilanjutkan dengan pembukaan mengaitkan pembelajaran minggu kemarin dengan yang akan diajarkan. Memberitahu materi yang akan diajarkan serta tujuan dari pembelajaran yang ingin dicapai. Adapun tujuan dari pembelajaran yaitu mahasiswa dapat menulis puisi yang baik dengan memperhatikan diksi, pencitraan,pemadatan bahasa, kata konkret,tema, dan amanat.

2. Kegiatan Inti

Kegiatan inti pada siklus 1 diawali dengan tanya jawab seputar puisi, tentang proses terciptanya puisi, unsur- unsur dalam puisi, dan hal-hal yang harus diperhatikan dalam pembuatan puisi. Setelah itu dosen/peneliti mulai 
menggunakan metode sinektik dengan langkah-langkah sebagai berikut:

- Dosen menentukan tema puisi yang akan dibuat oleh mahasiswa, temanya yaitu "wanita karier"

- Selanjutnya dosen memberikan stimulus kepada para mahasiswa, semua mahasiswa harus mencari satu kata yang menggambarkan wanita karier misalnya tangguh, kuat, cantik, permata, berkilau,indah, bahaya, dll, jika diibaratkan binatang buas wanita karier seperti singa,ular, lembut dll. Jika diibaratkan benda tajam wanita karier seperti pisau yang tajam, pedang dll. Menulis kata sebanyak mungkin ada yang positif ada yang negatif.

- Berikutnya membuat analogi dari katakata yang buat oleh para mahasiswa misalnya rapuh namun kuat, indah tapi berbahaya, cantik tetapi berbahaya dll.

- Selanjutnya para mahsiswa ditugaskan membuat analogi dari kata-kata yang tadi dibuat sebanyak-banyaknya.

- Langkah terakhir mahasiswa membuat puisi berdasarkan analogi kata yang sudah dibuat

Tabel 1. Hasil Observasi Siklus I

\begin{tabular}{|l|l|l|}
\hline NO & KOMPONEN & $\begin{array}{l}\text { HASIL PENGAMATN } \\
\text { INTERVENSI }\end{array}$ \\
\hline 1 & Keaktifan mahasiswa dalam pembelajaran & $\begin{array}{l}\text { Pada siklus 1 mahasiswa yang aktif } \\
\text { hanya beberapa orang, ketika disuruh } \\
\text { menyebutkan kata yang dianalogikan } \\
\text { dengan wanita karier masih banyak yang } \\
\text { diam. }\end{array}$ \\
\hline 2 & $\begin{array}{l}\text { Perhatian mahasiswa pada proses } \\
\text { pembelajaran }\end{array}$ & $\begin{array}{l}\text { Pada siklus 1 perhatian mahasiswa } \\
\text { terhadap materi dan tugas-tugas dapat } \\
\text { dikategorikan biasa atau kurang } \\
\text { antusias. }\end{array}$ \\
\hline 3 & $\begin{array}{l}\text { Kedisplinan mahasiswa dalam proses } \\
\text { pembelajaran }\end{array}$ & $\begin{array}{l}\text { Untuk kedisisplinan lumayan bagus tidak } \\
\text { ada yang terlambat dan mereka semua } \\
\text { mematuhi aturan kampus misalnya tidak } \\
\text { ada mahasiswa yang memakai kaos atau } \\
\text { tidak memakai sepatu. }\end{array}$ \\
\hline 4 & $\begin{array}{l}\text { Ketepatan mengerjakan dan mengumpulkan } \\
\text { tugas }\end{array}$ & $\begin{array}{l}\text { Pada siklus 1 mahasiswa diberi tugas } \\
\text { pertama menyusun kata-kata yang } \\
\text { diibaratkan dari wanita karier agak lama } \\
\text { berpikir, kemudian dalam penyusunan } \\
\text { analogi dua kata atau lebih juga sama } \\
\text { mereka agak lama berpikir, dan terakhir } \\
\text { membuat puisi dari kata-kata yang sudah } \\
\text { dibuat butuh waktu lama. }\end{array}$ \\
\hline
\end{tabular}

Rencana Pembelajaran Semester Siklus II

1. RPS siklus II dibuat setelah siklus I selesai dan diketahui belum mencapai target atau kemampuan yang diinginkan. Hasil siklus ke I penelitian ini ternyata kemampuan mahasiswa belum sesuai harapan, nilai rata-rata masih berada pada angka 73 walaupun angka tersebut masuk kategori berhasil namun bagi calon guru bahasa Indonesia yang nantinya akan mengajarkan kembali kepada para siswa nilai 73 dianggap masih rendah sehingga perlu kembali ditingkatkan. Hasil refleksi dari siklus I para mahasiswa masih kesulitan menentukan pencitraan dalam puisi, cara memadatkan bahasa puisi, menentukan kata konkret. Untuk amanat rata-rata mahasiswa sudah paham dan terdapat amanat dan tema dalam puisi yang mereka buat. Oleh karena itu peneliti memfokuskan pembelajaran pada 
pencitraan/imajinasi, pemadatan bahasa, dan menentukan kata konkrit.

\section{Proses Pembelajaran Siklus II}

Proses pembelajaran pada siklus II hampir sama dengan dengan siklus I yang membedakannya adalah pembelajaran lebih fokus pada pencitraan/imajinasi, pemadatan bahasa, dan menentukan kata konkrit. Memberikan stimulus kepada mahasiswa agar lebih aktif dalampembelajaran di kelas. Awal masuk kelas tanya jawab dengan mahasiswa lanjut menentukan tema setelah itu membuat analogi dari tema yang ditentukan sebanyak-banyaknya. Berikutnya menyususn puisi dengan memperhatikan pilihan kata/diksi, kata konkret, imajinasi, pemadata bahasa, dan amanat.

\section{Tabel 2. Hasil Observasi Siklus II}

\begin{tabular}{|l|l|l|}
\hline NO & KOMPONEN & $\begin{array}{l}\text { HASIL PENGAMATN } \\
\text { INTERVENSI }\end{array}$ \\
\hline 1 & Keaktifan mahasiswa dalam pembelajaran & $\begin{array}{l}\text { Pada siklus II mahasiswa lebih aktif tanya } \\
\text { jawab, mereka mulai paham embuat analogi } \\
\text { kata }\end{array}$ \\
\hline 2 & Perhatian mahasiswa pada proses pembelajaran & $\begin{array}{l}\text { Pada siklus II perhatian mahasiswa terhadap } \\
\text { materi dan tugas-tugas mulai antusias }\end{array}$ \\
\hline 3 & Kedisplinan mahasiswa dalam proses pembelajaran & $\begin{array}{l}\text { Untuk kedisisplinan lumayan bagus tidak ada } \\
\text { yang terlambat dan mereka semua mematuhi } \\
\text { aturan kampus misalnya tidak ada mahasiswa } \\
\text { yang memakai kaos atau tidak memakai } \\
\text { sepatu. }\end{array}$ \\
\hline 4 & Ketepatan mengerjakan dan mengumpulkan tugas & Pada siklus II tugas dikerjakan lebih cepat \\
\hline
\end{tabular}

\section{Analisis Hasil Pembelajaran}

Setelah selesai pembelajaran siklus 2, peneliti mengadakan analisis hasil observasi dan hasil tes. Hasil observasi pembelajaran terhadap mahasiswa sebagai berikut:

1. Dilihat dari keaktifan di dalam kelas mahasiswa banyak yang aktif baik bertanya maupun menjawab pertanyaan dan menyebutkan kata-kata yang berhubungan dengan wanita karier untuk bahan penulisan puisi.

2. Dilihat dari perhatian mahasiswa terhadap pembelajaran secara keseluruhan mereka mulai antusias mengikuti pembelajaran.

3. Setelah siklus 2 mereka mulai memahami sehingga dalam pembuatan puisi lebih cepat dibandingan dengan siklus 1.

Berikutnya analisis hasil tes menulis puisi pada mahasiswa PBSI tingkat II tahun ajaran 2019/2020 dari enam kriteria penilaian sebagai berikut:
1. Penilaian untuk pilihan kata yang tepat, pada siklus 1 mahasiswa masih kesulitan dalam memilih kata yang tepat untuk merangkai puisi setelah siklus 2 dan diberi beberapa contoh cara menggunakan pilihan kata yang tepat hasil tesnya meningakat banyak mahasiswa naik dari dari kategori 2 menjadi 3.

2. Untuk pencitraan pada siklus 1 paling banyak kategori 2 bahkan ada yang satu, pada siklus 2 dosen memberikan banyak contoh hasilnya pun meningkat.

3. Pemadatan bahasa sama dengan pilihan kata dan pencitraan yang awalnya mahasiswa kesulitan dalam memadatkan bahasa setelah siklus 2 mereka mulai bisa memadatkan bahasa dan hasil nilainya meningkat.

4. Kata konkret pada siklus 1 sama dengan yang seblumnya mahasiswa kesulitan dan setelah tindakan siklus 2 mereka mulai bisa menentukan kata konkret dan menerapkannya dalam puisi yang mereka buat. 
5. Untuk tema secara umum mahasiswa tidak kesulitan dan mereka bisa membuat puisi dengan tema yang jelas.

6. Amanat sebelum siklus 2 masih jarang yang mencantumkan amanat, setelah siklus 2 mahasiswa mulai memasukkan amanat dalam puisi yang mereka buat.

\section{Refleksi Hasil Pembelajaran}

Setelah pembelajaran pada siklus 2 terdapat peningkatan kemampuan mahasiswa dalam menulis puisi dengan menggunakan model sinektik. Peningkatan hasil observasi dari mulai keaktifan mahasiswa ketika proses pembelajaran, perhatian mahasiswa dari yang tadinya biasa menjadi antusias dan menyenangkan, untuk kedisiplinan para mahasiswa dari awal cukup disiplin, dan ketepatan dalam pengerjaan dan pengumpulan tugas setelah siklus 2 mahasiswa lebih cepat dalam membuat puisis dengan menggunakan model sinektik.

Hasil dari kemampuan mahasiswa melalui tes secara umum menigkat dan memuaskan tetapi tetap harus terus ditingkatkan, menulis adalah keterampilan bahasa yang paling sulit apalagi menulis puisi dibutuhakan kemampuan berbahasa yang mumpuni penggunaan diksi, pemadatan bahasa, pengetahuan dan imajinasi yang tiggi. Oleh karena itu perlu proses panjang dan sering latihan dalam kegiatan ini. Tidak hanya dosen yang harus serius dalam mengajari penulisan puisi ini tetapi mahasiswanya pun harus sungguh-sungguh dalam mempelajari puisi.

Analisis Data Peningkatan Kemampuan mahasiswa PBSI tingkat II tahun ajaran 2018/2019 dalam menulis puisis dengan menggunakan model sinektik

Berdasarkan data pada tabel siklus I dan II menunjukan adanya peningkatan yang signifikan pada kompetensi yang telah dicapai oleh mahasiswa selama pembelajaran. Seluruh mahasiswa dapat mengikuti tahapan-tahapan dalam pembelajaran yang diterapkan oleh peneliti. Keberhasilan ini merupakan keberhasilan mahasiswa, peneliti yang bekerjasama dalam melaksanakan penelitian ini. Hasil tes menunjukan pada siklus I nilai rata-rata 73 dan siklus II meningkat menjadi 83. Nilai terkecil pada siklus I yaitu 56 dan nilai terbesar 83 sementara pada siklus II nilai terkecil meningkat menjadi 67 dan nilai terbesar 94.

Jadi, berdasarkan hasil yang dicapai oleh mahasiswa, maka dapat dikatakan implementasi model pembelajaran sinektik dapat meningkatkan kemampuan menulis puis mahasiswa PBSI tingkat II tahun ajaran 2018/2019 Universitas Kuningan.

\section{KESIMPULAN}

\section{Simpulan}

1. Perencanaan tindakan pembelajaran berdasarkan masalah yang terjadi di kampus, maka dosen melakukan penelitian tidakan kelas dengan model pembelajaran sinektik. dengan langkahlangkah sebagai berikut.(1) menggunakan teknik tanya jawab anatara mahasiswa dan peneliti/dosen mengenai tema yang sudah ditentukan oleh dosen yaitu "wanita karier"(2) menggunakan teknik analogi langsung mahasiswa menganalogikan wanita karier dengan benda, hewan, kata sifat ada kata positif dan ada kata negatif. Mahasiswa harus mengumpulkan katakata tersebut sebanyak-banyaknya untuk dirangkai menjadi sebuah puisi (3) masing-masing mahasiswa disuruh menulis puisi dengan tema wanita karier. (4) menggunakan kriteria penilaian untuk mengukur kemampuan siswa dalam menulis puisi. Tindakan-tindakan tersebut termuat dalam Rancangan Pembelajaran Semester (RPS). 
2. Proses pelaksanaan pembelajaran menulis puisi dengan menggunakan model sinektik secara garis besar dapat digambarkan sebagai berikut. Pada awalanya dosen/peneliti melakukan tanya jawab dengan mahasiswa tentang puisi kemudian dosen memberikan tema (wanita karier), para mahasiswa disuruh menulis sebanyak-banyaknya kata-kata yang menganalogikan wanita karier misalnya analogi dengan kata sifat cantik, menawan, jelita, berbahaya dll. Analogi dengan binatang midalnya kijang, singa, burung merak, ular dll. Analogi dengan benda permata, jamrud, berlian dll. Kata kata yang dikumpulkan ada yang negatif ada yang maknanya positif. Selanjutnya setiap mahasiswa harus menulis puisi dengan kata-kata yang sudah ditulis sebelumnya. Maka jadilah sebuah puisi dengan tema wanita karier.

3. Hasil pembelajaran yang dicapai dapat dilihat pada pencapaian sebagai berikut. Pada siklus I, mahasiswa yang memperoleh nilai di atas 80 hanya ada lima orang dengan nilai rata-rata seluruh mahasiswa 73. Sedangkan pada siklus II siswa yang memperoleh nilai di atas 80 sebanyak 42 orang dengan nilai rata-rata seluruh siswa 83. Ini membuktikan bahwa model sinektik yang digunakan oleh peneliti efektif untuk meningkatkan pembelajaran menulis puisi pada mahasiswa PBSI tingkat II tahun ajaran 2018/2019 Universitas Kuningan.

\section{Saran}

Berdasarkan hasil penelitian tersebut, ada beberapa saran yang diajukan oleh peneliti kepada mahasiswa dan lembaga. Adapun saran-saran tersebut sebagai berikut.

1. Para mahasiswa harus lebih kreatif dalam menulis puisi, ide tidak datang setiap saan oleh karena itu jika ada ide harus segera dituangkan ke dalam tulisan untuk meghindari lupa. Selainitu kegiatan menulis puisi ini harus ditingkatkan bahkan dianalisis secara serius agar mendapatkan hasil yang maksimal untuk bekal nanti menjadi guru bahasa Indonesia.

2. Untuk lembaga agar memberikan fasilitas kepada para mahasiswa untuk mengembangakan bakat dan minatnya agar mereka bisa berkembang secara maksimal.

\section{DAFTAR PUSTAKA}

Arikunto, Suharsini.(2010). Prosedur penelitian. Jakarta: Rineka Cipta.

Chaedar.(2007).Pokoknya Menulis. Bandung: Anggota IKAPI.

E. Mulyasa.(2013). Praktikpenelitian Tindakan Kelas. Bandung : Remaja Rosdakarya.

Hamdani.(2011). Strategi Belajar Mengajar. Bandung: Pustaka Setia.

Heryadi, Dedi. (2008). Metode Penelitian Bahasa. Tasikmalaya : Universitas Siliwangi Tasikmalaya.

Huda, Miftahul.(2014). Model-Model Pengajaran dan Pembelajaran. Yogyakarta : Pustaka Pelajar.

Joyce, Bruce dkk.(2009). Models of Teaching. Yogyakarta: Pustaka Pelajar.

Listini, L., \& Saraswati, S. (2017). Meningkatkan Kemampuan Menulis Cerpen Melalui Model Pembelajaran Sinektik Siswa Kelas Vii Smp Sandika Sukajadi. Jurnal Bindo Sastra, 1(1), 24-27.

Muslich, Masnur.(2008). KTSP. Jakarta: Bumi Aksara.

Rozak,Abdul.(2012). Menulis Skripsi Itu Tidak Sulit. Cirebon : Unswagati Cirebon.

Rusman.(2012). Model-Model

Pembelajaran (Edisi Kedua). Jakarta: Raja Grapindo Persada.

Subana dan Sunarti. (2009). Strategi Belajar Mengajar Bahasa Indonesia. Bandung : Pustaka Setia.

Suntini, S. (2016). Penggunaan Model Sinektik Untuk Meningkatkan Kemempuan Menulis Pada Pembelajaran Wacana Naratif Siswa 
Kelas XI SMK Muhammadiyah Jalaksana Tahun Ajaran 2014/2015. FON: Jurnal Pendidikan Bahasa dan Sastra Indonesia, 9(2).

Supriyadi, S. (2016). Peningkatan Kemampuan Menulis Puisi Dengan Model Sinektik. Jp2sd (Jurnal Pemikiran dan Pengembangan Sekolah Dasar), 1(3), 201-211.
Sukmadinata, Nana Syaodih.(2012). Metode Penelitian Pendidikan.Bandung : Rosdakarya. Tarigan, Henry Guntur.(2008). Menulis Sebagai Suatu Keterampilan Berbahasa. Bandung: Angkasa.

Wirawan, Bimo.(2008). Menjadi Penulis Mahir dalam 7 Langkah. Yogyakarta: Pelangi Multi Aksara. 